\title{
УВАЖЕНИЕ СТАРШИХ У АДЫГОВ: ВОЗНИКНОВЕНИЕ И ТРАНСФОРМАЦИЯ ТРАДИЦИИ*
}

В статье рассматривается укоренившийся в адыгском обществе комплекс норм и правил поведения по отношению к людям старшего возраста. Целью исследования является определение мотивов возникновения социального института уважения стариих и причин его трансформации, а также изучение динамики развития традиции с момента зарождения до наших дней. Поскольку автор видит истоки института не только в причинах нравственного характеpa, но и в тесной взаимосвязи появления установок почитания старших с хозяйственно-экономическими устоями общества, в работе предпринята попытка отследить изменения, произошедшие в материальном базисе адыгов за последние 200 лет, и определить степень влияния на нормы проявления уважительного отношения к старшим процессов урбанизации адыгского общества. Автор приходит к следующим вывводм: адыси вплоть до второй половины ХІХ века жили в основном за счет многоотраслевого натурального хозяйства, что ставило семьи перед необходимостью иметь в доме много рабочих рук. В условиях, сложного хозяйствования, а также земельного права, которое полностью находилось в руках старшего в семье мужчины, складывались предпосылки для появления института уважения старших. Последовавшее за окончанием Кавказской войны вовлечение в российскую экономику, а позже Октябрьская револючия, изменивщие принципь земельного права, ограничили власть адыгского «большака». Процессы урбанизачии, в которые адьги начали массово включаться в конце XX века, привели к трансформации некоторых традиционных правил внешних проявлений уважительного отношения к старшим.

Ключевые слова: адьги, черкесы, уважение стариих, хабзэ.

В последние десятилетия, в условиях постоянно меняющегося мира, усложнения жизни и связанных с этим социальных и нравственных потрясений многие незыблемые традиционные устои общества заметно пошатнулись. Россия, а соответственно и населяющие ее народы окунулись в водоворот событий конца 1980-х и начала 1990-ых гг., не остались в стороне и адыги. Всплеск национального самосознания, который был спровоцирован «парадом суверенитетов», получение республиканского статуса Адыгейской автономией, массовое возвращение соотечественников, волею судьбы оказавшихся за пределами Родины в лихие годы середины XIX века, вступили в противоречие с резко меняющейся действительностью и процессами глобализации общества. Получение нового статуса, возможность сохранения самобытности, в т.ч.

Донежук Мурат Юсуфович - аспирант, стажер-исследователь, Институт этнологии и антропологии РАН (119991 Москва, Ленинский просп., 32а). Эл. почта: donmur@iea.ras.ru.

* Статья подготовлена при финансовой поддержке РФФИ грант «19-09-00482 А» 
защиты языка и традиций в соответствии со своей Конституцией и многие другие аспекты сулили возможность укрепления национального самосознания. Но крушение обыденной жизни, изменение материальной базы, внутри которой сохранялись вековые обычаи и нормы жизни, замена традиционных институтов на институты государственные, привели к невозможности реализации выработанного многими поколениями потенциала. Постоянно растущее давление современности, привело к определенному пересмотру некоторых положений в институте уважения старших.

В рамках этой статьи, мы рассматриваем уважение старших как социальный институт. Для определения понятия «уважение», мы используем трактовку И.С. Кона: «Уважение - одно из важнейших требований нравственности, подразумевающее такое отношение к людям, в котором практически (в соответствующих действиях, мотивах, а также в социальных условиях жизни общества) признается достоинство личности» (Кон 1981: 353). Также, Кон указывает, что составной частью уважения является чуткость, вежливость, внимательное отношение к убеждениям и стремлениям, а вместе с тем деликатность и скромность (Там же). Тем самым, под словосочетанием «уважение старших», мы подразумеваем вежливое, внимательное, деликатное отношение к людям старшим по возрасту, проявляющееся не только в заверениях, но и подтверждающееся реальными действиями, которое поощряется обществом и воспринимается нравственным. Под определением социальный институт, мы подразумеваем «исторически сложившиеся, устойчивые формы организации совместной деятельности», в рамках которой «осуществляется социализация индивидов, обеспечивается преемственность в использовании культурных ценностей, передаче навыков и норм социального поведения» (Гвишиани, Лапина 1989: 89). Т.е., для нас, институт уважения старших - это форма общественного взаимодействия, поощряющая вежливое, внимательное, деликатное отношение к старшим по возрасту представителям социума, осуществляющая меры по преемственной передаче этих установок.

Целью этого исследования является изучение причин трансформации института уважения старших у адыгов. Для достижения цели были поставлены следующие задачи: 1. определение изменений материального базиса адыгов, являющегося, на наш взгляд, одной из важных основ института уважения старших; 2. изучение картины, отображающей то, как выглядело уважение старших у адыгов; 3. рассмотрение влияния на этот институт урбанизации адыгов.

Важность исследования функционирования института уважения старших в современных реалиях обусловлена углубляющимся кризисом национального самосознания, которое в значительной степени утратило целостное представление о нормах, принципах нравственности и человечности. Поэтому, важно изучить, как формировалось почтение старших у адыгов. Выявив процесс выстраивания подобных отношений, можно будет проследить как изменился этот институт в наши дни.

Тема «уважения старших» или «института уважения старших» в первую очередь рассматривается в научных трудах с точки зрения педагогики, в то время как в исторических науках упоминается только в контексте института семьи. Так, Б.Х. Бгажноков являющийся автором книги «Социальная организация семьи», в которой анализируется структура, организация и представления о семье у адыгов, не останавливается в своей работе на теме уважения старших, как отдельном предмете исследования. В монографии «Основания гуманистической этнологии» Бгажноков также рассматривает уважение старших в контексте семьи. М.А. Меретуков в монографии «Семья и брак 
у адыгских народов (XIX - 70-ые годы XX в.)» уделяет вопросу уважения старших не очень много внимания, включая его в комплекс семейных отношений в адыгском обществе. Э.Л. Коджесау, сделав акцент на патронимической структуре семьи, отметил, что власть и полномочия у главы семьи, обычно старшего в роду, весьма обширны. Также он отследил важную роль старшей женщины в адыгской семье (Коджесау 1962: 115-120). Очень интересной для нашей темы оказалась монография А.С. Марзей «Черкесское наездничество - «ЗекІуэ» (Из истории военного быта черкесов в XVIII первой половине XIX в.)», в которой рассматривается организация военных походов адыгов. В этом контексте исследователь упоминает и показывает, что даже на войне невозможно было отказаться от разделения общества по старшинству. Также мы можем отнести к полезной для нас историографии статьи, содержащие этнографические, тесно переплетенные с вопросом социального устройства данные. Так, автор работы «Кавказ: Адаты горских народов», рассказывая об устройстве народов Кавказа и основываясь на разных донесениях чиновников, упоминает и то, как адыги внимательны и уважительны к старикам. При этом, наличие информации по другим народам Северного Кавказа, позволяет сравнить во многом похожие установки, которые тем не менее, имеют достаточно серьезные различия. Особо хотелось бы выделить труды Султан Хан-Гирея, которые были объединены в книге «Султан Хан-Гирей: Избранные труды и документы». Хан-Гирей, проживавший среди адыгов с самого рождения и получивший хорошее образование, стал одним из тех выходцев адыгской знати, кому посчастливилось попасть в ряды Лейб-Гвардии Кавказско-Горского полуэскадрона его Императорского Величества. В своих трудах, он проанализировал многие аспекты жизни адыгов в первой половине XIX века. Он также затронул вопрос уважения старших и что особенно интересно, дал критику аталычества, как института, который за счет своих внутренних противоречий приводит к грызне между родными братьями и прививает ребенку большую любовь к аталыку (воспитателю), нежели к родителям.

С самого начала стоит разобраться, в чем заключается необходимость такого поведенческого комплекса, как «уважение старших». Важное место в этой связи занимают методы производства и восполнения материальных благ, таких как пища, одежда, жилье, орудия труда. На наш взгляд, натуральное хозяйство и уровень развития средств производства привели к образованию социальных институтов, одним из которых является уважение старших. Земли, населенные адыгами, левый берег реки Кубань, изобилующий плодородной почвой, удобной для организации пастбищ и пашень благоприятны для разведения крупного и мелкого рогатого скота, а также активного земледелия. «Мелкая вспашка земли, боронование полей перед севом, огораживание участков лесополосами, применение органических удобрений, мелиорирование, нивелировка местности, террасирование горных склонов, севооборот - таков неполный перечень агротехнических приемов, которыми в совершенстве владел горский крестьянин» (Шеуджен 1989: 31). Эти методы хозяйствования способствовали разделению труда в больших адыгских семьях, что позволяло возделывать обширные участки земли, освобождать от лесных массивов землю под пашни, заготавливать дрова и заниматься отгонным скотоводством. О необходимости больших семей в тех условиях упоминают 3.А. Цеева и М.Н. Губжоков: «Главной причиной сохранения большой семьи являлось господство натурального хозяйства, в условиях которого многоотраслевая деятельность была возможна только в рамках крупных семейных общин» (Цеева, Губжоков 2017: 181). Показателен пример 
русских переселенцев, которые в XIX в. в поисках «лучшей доли» отправились на теряющие своих хозяев земли Северного Кавказа. Как отмечают Л.Б. Заседателова и А.Е. Солдатова, одной из причин образования больших семей в среде русских переселенцев (которые впрочем сами переселялись из регионов где «процветали большие патриархальные семьи), стало наличие обширной территории, пригодной для пашень и пастбищ, где требовалось много рабочих рук (Алгоритмы 2018: 379).

Показательно определенное сходство структуры славянской семьи с адыгской. М.Н. Покровский в книге «Русская история» описывал славянскую семью следующим образом: «Руководство всея семейным хозяйством и военная дисциплина, необходимая для обороны этого хозяйства, дают в его руки (отца - прим. М.Д.) громадную власть... О сопротивлении домовладыке не может быть и речи: господин-отец - самодержец в широчайшем значении этого слова. Он распоряжается всеми членами семьи, как своею собственностью. Он может убить или продать сына или дочь, как продают свинью или козу» (Покровский. 1922: 22). В устройстве адыгской семьи можно заметить те же устои и правила поведения: «Дети состоят в безусловном повиновении родителей своих, и воля отца есть для них непреложный закон, пока не достигнут совершеннолетия...Сын выполняет в точности приказания отца и не может сопротивляться оным; за неисполнение же оных отец имеет полное право поступать с ним по своему произволу» (Кавказ: Адаты 2010: 91).

Подобные сходства свойственны патронимической структуре семьи, которые могут существовать невзирая на разницу во времени, а отталкиваясь лишь от конкретного уровня общественно-хозяйственных отношений (Косвен 1963: 98). Интересно, что схожесть проявляется даже в значениях слов, которыми обозначались патронимии у славян и адыгов. Так, славянское слово вервь происходило от «вязать», а адыгское хьабль, обозначавшее хозяйственное объединение родственников и имеет в корне слово блэ «заплетать». В обоих случаях основной мотив родственного узла является центральным (Бгажноков 2010: 59).

Но пример Покровского не случаен еще и потому, что адыгская семья на протяжении длительного периода времени являлась еще и военно-политическим образованием. Существование в условиях отсутствия центральной власти и государственного института наказания, заставляло семью заниматься вопросом обороны.

Эффективным способом упрочнения власти и консолидации сил вокруг главы семьи, стал земельный вопрос. Так, контролируя производительные силы и являясь собственником земли, отец мог препятствовать оттоку из дома членов семьи, а также концентрировать их на определенном фронте работы: «Никто из сыновей, достигнув совершеннолетия при жизни отца, не имеет права требовать выдела себе части имения, а большей частью все живут вместе с отцом, хотя и вступят в брак; по смерти же его разделяются оным, как сказано выше» (Кавказ: Aдаты 2010: 91). Можно провести сравнение с чеченскими адатами, которые также касаются имущественного вопроса в семье. Отец в чеченской семье является представителем высшей власти, но, тем не менее, до определенного срока: «На домашнее имущество отец и сыновья имеют равное право, и последние могут заставить первого, когда им вздумается, делиться с ними, и по адату предоставляется им одинаковая доля с отцом» (Кавказ: Adambl 2010: 228). Но несмотря на то, что в чеченской семье, как и в адыгской, отец является носителем власти, она ограничивается возрастом детей, которые после достижения совершеннолетия становятся независимыми. В адыгской же семье отец 
имеет исключительные права собственности вплоть до своей смерти, тем самым сосредотачивая неограниченную власть в своих руках.

Здесь стоит вернуться к теме патронимии в рамках земельного и производственного вопросов. Будучи основанной на принципах родовой связи, патронимия выполняла роль защитную, отвечала за вопросы воспитания детей и в немалой степени занималась хозяйственным регулированием. Так, патронимия у адыгов основывалась на близости семей, имевших общего предка, от имени которого образовывалось патронимическое название за счет прибавления окончания «къо», что означало «сын»: Шумафыкъо - Сын Шумафа; Болэтыкъо - Сын Болэта. Как отмечает Э.Л. Коджесау, такие родственные структуры имели общую хозяйственную базу, семьи из одной патронимии селились компактно, образовывая целые кварталы. В порядке вещей были общие орудия труда, скот, загоны, печи. Не считалось зазорным использовать плуг или прочие орудия труда члена патронимии, наоборот, отказ в предоставлении помощи, оценивался как оскорбление (Коджесау 1962: 117). Следовательно, мы можем говорить, что мужчина сосредотачивал вокруг себя родственников (детей) за счет своей земельной собственности. Благодаря земле он получал рычаги воздействия, которые обуславливали его полное господство над домочадцами.

Роль регулирования и управления в патронимии занимал самый старший в роду мужчина: «Во главе патронимии стоял старшина, который давал советы, распоряжения по всем вопросам, касающимся патронимии в целом. Чаще его выбирали из семьи, которая считалась первопоселенцами и из которой происходил предок патронимии. Если же в такой семье не было подходящего кандидата, старшину выбирали из другой семьи, наиболее близкой к семье первопоселенцев. Главой патронимии, таким образом, был обязательно старейший, который назывался своим личным именем, без прибавлений патронимического, и в конце концов становился со временем основоположником одной из вновь образующихся патронимий» (Там же). Практически во всех сферах материальной деятельности, будь то скотоводство, земледелие, садоводство и т.д., руководящую роль играло более опытное старшее поколение (Меретуков 1987: 50). Правило, что старейший в роду становился главой патронимии, распространялось в том числе и на дворян. Так, в романе «Черкесские предания» есть упоминание, что старший в роду князь становился «князем-старшиной». Такой титул давал большую власть, но только, если последний мог в полной мере использовать все полученные выгоды (Султан Хан-Гирей 2009: 321).

Правило старшинства не обходило и старшую женщину в роду - «гуащээ», которая становилась носителем власти в женской части патронимии и главным хранителем традиций и обрядов. Именно ей отводилась роль члена семьи, который первым зажжет огонь в очаге нового дома. Гуащэ не была ограничена жесткими рамками субординации, а потому могла проще и свободнее общаться с подчиненной ей частью рода (Бгажноков 2003: 228). Особенностью данной системы являлось не только личное уважение и исполнение воли старшего или старшей в роду, но также почтительное уважение к старшей семье в целом, дом который становился местом собрания и решения важных вопросов рода.

В процессе своего развития норма «уважения старших» вышла за рамки некоего «инструмента», став самостоятельной частью культуры. В адыгском фольклоре и эпосе имеются упоминания о далеких временах, когда отношение к старшим не было таким безусловным. В народной памяти сохранилось сказание, повествующее, что в древности 
адыги скидывали стариков со специальной скалы. Но один мужчина не смог решиться убить своего отца и сохранил ему жизнь. В дальнейшем мудрость и ум родителя уберегли жителей аула от голода, а прознав о том, кто давал ценные советы, адыги перестали убивать стариков и окружили последних уважением и почетом (Хуm 1989: 52).

Занимательный сюжет, приводит известный нартовед А.М. Гадагатль: «Беспределен в своих правах Хасэ (Совет), выносящий смертные приговоры состарившимся, непригодным к труду и другим лицам. По решению Хасэ заочно осужденный вызывался на сборище нартов. Состарившегося нарта, не способного уже быть полезным обществу, ставили около сэнэф к1ад (бочка с вином), вручали ему ковш. Он, произнося хохы (тосты), пил за здоровье нартов. Он доходил до сильного опьянения. В таком виде его отводили в определенное место (обычно в дол) и там отсекали ему голову. В сказании о нарте Орзэмэсе повествуется о том, что таким образом нарты хотели лишить жизни «бесполезного» Орэзмэса, но умной Сэтэнай удалось спасти его с помощью своего сына Саусырыко, которого она содержала тайно в подземном доме (ч1ыунэ) до совершеннолетия» (Гадагатль 1967: 120). Традиция отсылает нас в глубокую древность, в эпоху железа, с которой А.М. Гадагатль связывает зарождение нартского эпоса (Там же: 118-119).

Оставаясь в рамках сюжета о Саусырыко, который спас отца и тем самым положил конец убийствам стариков, стоит вспомнить о наместнике Тенгри-Хана (Бога неба) - Кагане. В тюркском мире Каган обладал абсолютной полнотой власти. Этот титул имеет глубоко уходящие в историю корни. Так, д.и.н. Т.С. Жумаганбетов приводит упоминания титула Каган, датируемые еще IV-V вв. н.э. и даже раньше (Вестник Челябинского 2008: 14). Но Каган нам важен не столько своей датировкой, а своей особенностью, которая роднит его с преданием о Саусырыко и Орзэмэсе: «В период обрушившихся бедствий убивали не простого древнего старца, а полного сил могущественного властителя, наместника Тенгри-хана (бога неба) на земле. Он обязан был представительствовать перед разбушевавшимися стихиями и просить, а скорее, требовать у верховного божества прекратить испытания и беды, посланные им на его народ» (Велецкая 2003). Т.е. само по себе убийство является своего рода жертвоприношением: «Итак, убийство уважаемых общиной, обществом стариков, убийство отца, идущего на смерть ради жизни, ради спасения от несчастья своей семьи, своего рода и, наконец, своего государства, как в случае с каганом, уже не кажется таким невероятным, чудовищным варварством, как это представлялось нам вначале» (Там же). Стоит сказать, что тут присутствует оговорка: могли убить не только состарившегося Кагана, но и еще молодого, полного сил монарха. Такой поворот событий зачастую был связан с особенностью назначения владыки. Перед началом властвования будущего Кагана душили, доводя его до беспамятного состояния. В этот момент задавался вопрос о том, сколько тот будет править. От названной цифры зависел срок правления, по истечению которого, даже молодого Кагана убивали (Там же). При сравнении этих двух примеров мы видим определенные параллели: в обоих случаях предполагалось убийство либо состарившегося, либо уже не способного выполнять свои функции властителя (семейного в том числе); в обоих случаях мы говорим о достаточно древних формах организации. Как в случае с нартом Орземесом, который состарившись потерял прежнюю силу и авторитет на сборище нартов, так и утративший возможность защищать своих подданных Каган, являются частью представлений о «немощном человеке» ставшем обузой для общества. 
Учтем, что физическая смерть в традиционном представлении адыгов как, впрочем, и у многих других народов не являлась концом жизни. После жизни земной наступало время встречи с богами и духами, тот самый момент, когда старший в семье мог заступиться за своих еще живых близких. А уважаемый в обществе человек имеет больше преимуществ в общении с богами или духами.

Итак, мы можем сделать вывод, что уважение к старшим это результат переплетения экономических факторов, основанных на праве собственности, где не последнюю роль играет и мировоззренческий комплекс. Тот самый комплекс, который в главном собственнике, т.е. в старшем, видит заступника перед богами и духами. Естественно, что по прошествии времени, эта конструкция обрастала «мясом»: утверждались нормы обращения к старшему, поведение в присутствии старшего, почитание предков и многое другое.

Мы опираемся в своих выводах на сюжет о Саусырыко и Орзэмэсе с определенной оговоркой. Можно согласиться с А.М. Гадагатль, что «будучи по своему типу сказочно-мифологическим, нартовский эпос не может быть признан историческим в том смысле, что главным содержанием его являются какие-либо конкретные исторические события и сюжеты. Но это не лишает, однако, нартовский эпос исторической значимости... В нем с исключительной художественной силой и правдивостью изображена историческая реальность: древний хозяйственный и общественный уклад жизни, обычаи и быт людей далекого прошлого, их психология и мировоззрение» (Гадагатль 1967: 28). Т.е. мы допускаем использование сюжета с нартом Саусырыко и его отцом Орзэмэсом, оговаривая, что он не может быть исторически достоверным во всех деталях. Мы используем лишь центральную тему, которая описывается в текстах о спасении Орземеса, как попытку передачи древних обычаев и нравов.

Суть правила уважения старших у адыгов отражает народная пословица: «Кто не уважает старшего, тот сам в старости не получит уважения» или ее вариация «Родителям воздай свой почет - твой сын его тебе вернет». Это нерушимый принцип, определяющий поведение человека в обществе старших, предостерегающий от нечаянных оплошностей. С самого малого возраста разграничение статуса «старшего» и «младшего» производилось особенно явно и подчеркнуто. Так, в присутствии старшего запрещалось сидеть, даже если младшему это предлагалось неоднократно: «Оба брата находятся здесь вместе со своими аталыками, или воспитателями, и похоже, здесь нет (как некоторые мне о том говорили) никакой помехи тому, чтобы они свободно входили в дом своего отца; единственное - они никогда не сидят в его присутствии и не едят, не отвернувшись» (Бэлл 2007: 120).

Если в комнату вошел старший, обязательно предписывалось встать. Впрочем, этот аспект касался абсолютно любого человека, о чем говорит и Дубровин: «Уважение к старшим по летам распространялось часто и на невольников, которые не исключались из этого правила» (Дубровин 1927: 95). Привитию подобного поведения способствовала общая обстановка в семье, которая показывала ребенку с первых дней жизни, какое отношение к друг другу царит в наименышей ячейке общества. Воспитание дочери в мягкой обстановке, перед взором которой разворачивается картина обходительного и внимательного отношения к дедушке или бабушке со стороны родителей, как нельзя лучше воспитывало в ребенке подобные черты (См.: Сообцикова 2010: 163). Тем более, что непочтительное отношение или даже оскорбление старшего вне зависимости от пола, подвергалось общественному порицанию и наказанию (См.: Бгажноков 2003: 227). 
Подобный «миру» дочки в семье, складывался и мир мальчика, правда место это не находилось в большом доме, где постоянно хлопотали с делами старшие. Уважение к старшим у мальчика воспитывалось в первую очередь в кунацкой. Кунацкая отдельный гостевой дом, был местом сосредоточения острейших умов аула, пристанищем путешественников, где можно было подчерпнуть народной мудрости и наяву ощутить, как выстраивались отношения между младшими и старшими. Если мальчик, в чей дом пришел гость, был младшим в семье, то ему полагалось исполнять роль прислуживающего гостям. Подобная роль была весьма почетной и завидной, т.к. мальчик, стоявший около дверей, слышал все, что говорили старшие. В кунацкой обсуждались последние новости, разбирались случаи из жизни, рассказывались истории, пелись песни о подвигах героев старины и современности. Являясь местом сосредоточения знаний адыгского мира, кунацкая давала множество знаний подрастающему поколению. Даже в том случае, когда конкретная семья не имела своей кунацкой, а в ауле гостевал гость, мальчишки отправлялись к пристанищу путника.

Путешествия также являлись местом, где возрасту воздавался почет. В пути места старшего и младшего были строго регламентированы: младший располагался слева от старшего вне зависимости от того, пешее было движение или же верхом. Чтобы можно было определить старшего в партии всадников, нормы построения и движения группы в зависимости от ситуации несколько видоизменялись. Таким образом, партия разбивалась на группы по три всадника, где по центру располагался самый старший, слева от него средний по возрасту, а справа двигался самый младший. Такое построение позволяло не перестраиваться, если бы младшего отправили по поручению, ведь тогда, средний оставался слева от старшего, оставаясь готовым, помочь более опытному товарищу: «Молодые люди, по обычаю, прислуживали старикам, потому что прислуги никому иметь с собой не полагалось» (Марзей 2004: 118).

Походы имели и другой аспект, где важно уважение к старшим. Так по сведениям Султана Хан-Гирея, весной и осенью, князья собирали партии для наездничества и походов. В результате угонов скота, похищения людей добыча делилась на равные части между всеми участниками партии: «начиная со старшего летами, выбирает часть, которая ему более понравится; и таким порядком раздел добычи продолжается до самого конца. Здесь оказывается такое уважение старости и вообще возрасту, что всякий человек из партии, хотя бы он был просто повар, но старее князя летами, прежде этого последнего имеет право выбрать ту часть, которая ему понравится» (Султан Хан-Гирей 2009: 214). Естественно, что князь имел определенные права на захваченную добычу, поэтому ему отводилась определенная, неприкосновенная часть.

Особой статьей «дорожного» этикета являлось поведение всадника при встрече со старшим и не только старшим по возрасту: «Согласно этикету при встрече с почтенным старцем, с уважаемой пожилой женщиной, с признанной красавицей селения всадник непременно должен был спешиться за 20-50 метров до приближения к ним. Стоя на месте, он почтительно пропускал старших справа от себя» (Сообцзокова Н.И. 2010: 127). Обращение к человеку, тем более к старшему, женщине или представителю более высокого сословия сидя на лошади, могло восприниматься как оскорбление. Тем не менее, были и исключения: «Прежде чем вступить в разговор с женщиной или старшим по возрасту или рангу мужчиной, всадник обязан был предварительно спешиться с коня или, если обстоятельства не позволяли этого, привстать на стременах» (Там же). 
О разнице статуса и положения у младших и старших, очень красноречиво свидетельствует описанное в «Адатах горских народов» право наследования собственности усопшего отца: «Старший сын имеет преимущество: сверх своей части, он имеет право выбирать себе из каждого рода вещей по одной лучшей, например: одну лошадь, одного быка, одну шашку и пр. Младший сын получает одну какую-нибудь вещь, например лошадь или шашку. Средний сын получает только свою часть» (Кавказ: Адаты 2010: 104). Кроме привилегий материального плана, старший сын после смерти отца получал также и власть и уважение: «Старший брат в отношении к младшим, заступает некоторым образом место отца: пред ним без его приглашения не садятся младшие, а равно и за одним столом с ним не станут есть до тех пор, пока он их к тому не пригласит. Младший брат во всем оказывает услужливость, и где нет прислуги, там он для старшего заменяет ее» (Султан Хан-Гирей 2009: 250). Дубровин замечает, что младший не может проронить и слово перед старшим, будь то отец или брат (См.: Дубровин. 1927: 95). Тем не менее, бывали случаи, когда предпочтение отдавалось сыну, пусть не самому старшему, зато более опытному в разного рода делах (Меретуков 1987: 51). Следовательно, несмотря на жесткий стержень, по которому «дети находились в строгом повиновении у родителей, все их указания и распоряжения выполнялись беспрекословно, в семье соблюдался общий принцип подчинения младших старшим» (Там же: 358), бывали пусть и редкие, но все-же исключения. Хан-Гирей отмечает, что если дети бывали воспитаны аталыками, то система почтения старшинства могла давать сбои. Так, зачастую, отсутствовала привязанность родителей к детям, как и последних к родителям. А взаимоотношения братьев, воспитанных у разных аталыков, Хан-Гирей характеризует как: «друг друга не щадят, как лютейшие звери» (Султан Хан-Гирей 2009: 235-236).

Конечно, система «уважения старших» у адыгов не была настолько гибкой, чтобы без «утрат» пережить период мухаджирства в XIX веке. Изменение норм хозяйствования и землевладения, связанные с вхождением в государственную структуру Российской империи, затрудняли возможности для отгонного скотоводства, а также организации новых пашень за счет освобождения лесных массивов.

Дополнительные коррективы в жизнь адыгов внес XX век. После издания декрета о земле, а также коллективизации прежнее устройство семьи, основанное на старых земельных отношениях, стало «тяжеловесным». Отсутствие частной собственности на средства производства, к которым относилась в первую очередь земля, в правовом плане вырывало из рук адыгского «большака» имущественную власть над домочадцами. Для получения земельного участка достаточным было отделиться от большой семьи, благодаря чему могла отпасть необходимость в сложной структуре семьи. Так, гражданский кодекс РСФСР от 11.06.1964 года, предписывал: «Статья 130. Выдел из колхозного двора': При выходе одного или нескольких членов колхозного двора из его состава выдел доли в натуре производится с таким расчетом, чтобы не лишить двор необходимых для ведения его подсобного хозяйства построек, скота и сельскохозяйственного инвентаря... Право требовать выдела имущества при выходе из состава двора имеют члены двора, достигшие шестнадцати лет» (Гражданский 1964). Право на распоряжение имуществом, переданное в пользование колхозного двора, а не принадлежащее «боль-

\footnotetext{
${ }^{1}$ Колхозный двор - это семейно-трудовое объединение лиц, все или часть которых являются членами кол-хоза, выступающее во внешних и внутренних отношениях как единое целое. (Основы 1970: 302).
} 
шаку», также сказалось на значимости последнего: «Статья 127. Владение, пользование и распоряжение имуществом колхозного двора: Владение, пользование и распоряжение имуществом колхозного двора осуществляется с согласия всех его членов» (Там же). Более того, начавшаяся массовая коллективизация уничтожила натуральное методы хозяйствования (См.: Меретуков. 1987: 111), что привело к отпадению в необходимости наличия большой семьи, как средства производства благ (Так же: 113).

Изменения в системе образования при Советской власти, а точнее появление по-настоящему массового образования, в том числе на национальных языках имело большое значение. Образование, благодаря которому новые поколения получали больше знаний, чем предыдущие, подрывали основы «незыблемости» знания старших, явившись своеобразной платой за движение вперед. Великая Отечественная война унесла жизни многих мужчин, которые были воспитаны еще «традиционной» культурой, не успев передать ее подрастающей молодежи. В 1987 году Меретуков дал следующую характеристику произошедшим изменениям: «Равным образом изменились отношения между старшим и младшим поколением семьи. Подросшие дети ведут себя с родителями и другими старшими родственниками несравненно более свободно и непринужденно. Это также понятно: исчезла частнособственническая основа родительской власти, некогда делавшая детей полностью зависимыми от главы семьи» (Меретуков 1987: 360).

Период с 1989 по 2002 годы стал эпохой активной урбанизации адыгов. Так, в 1989 году в городах проживало 31841 адыгов. В это же самое время численность сельского населения составляла 63598 человек (Всесоюзная 1989). На момент переписи 2002 года городское население практически удвоилось и насчитывало 60053 человека. При этом сельское население не стало меньше, а наоборот увеличилось, составив 68475 человек (Всероссийская 2010). За следующие восемь лет численность городского и сельского населения уменьшилась. Так, городское население насчитывало 56980 человек против 60053 человек в 2002 году, и 67855 человек сельского населения против 68475 в 2002-м (Всероссийская 2010). Тем не менее, за последние 10 лет можно предположить, что доля городского населения по отношению к сельскому возросла. При этом, вполне возможно, что выявить эту ситуацию будет не совсем просто, т.к. в адыгском обществе имеется тенденция переезда в города с сохранением своей аульской прописки.

Вопрос увеличения доли городского населения в рамках исследуемой темы является важным, т.к. изменение условий жизни и включение молодежи в новые отношения приводит к изменениям во всех традиционных институтах, в том числе и в институте уважения старших. Контроль аульского населения и вероятность получать репутационые санкции становятся менее значимыми. Влияет и тот фактор, что все города и поселки городского типа в Адыгее имеют пеструю национальную картину, где адыги не являются большинством. Тем самым, жесткие рамки размываются и не выдерживают в борьбе с городским ритмом жизни. Но нельзя сказать, что из-за этих условий уважение старших уменьшается. Правильней было бы говорить о переходе его в новые формы.

Например, общественный транспорт, особенно маршрутное такси, становится местом, где невозможно соблюдать правило, при котором младший не должен садиться перед старшим. Ситуация усугубляется тем, что количество людей становится просто огромным и из-за этого не всегда можно определить кто старше, а кто 
младше. Но и в этой, казалось бы, патовой ситуации смогло проявиться уважение к возрасту. Так, есть негласное правило, по которому маршрутное такси делится не несколько зон: 1. пассажирские сиденья на уровне водителя, где есть отдельная, высоко расположенная дверь; 2. пассажирские сиденья в центре салона, в непосредственной близости от основной двери; 3. пассажирские сиденья в задней части салона, максимально далеко расположенные от дверей. В зоне 1 чаще всего садятся люди среднего возраста, преимущественно мужчины. Зона 2 предназначена для пожилых людей, а зона 3 - для младшего возраста. Объясняется это тем, что в зоне 1 находится два пассажирских места, и возможна ситуация, из-за которой придется попросить старшего выйти из транспорта, чтобы младший смог выйти на своей остановке. Подобное поведение по отношению к старшему считается неприличным, поэтому это место обычно оставляется для мужчин среднего возраста. Зона 2, расположенная непосредственно около двери, позволяет пожилым людям не протискиваться через ряды в самый конец салона, в то время, как это «неудобство» оставляется на откуп младшему поколению. Естественно, что смешанное население, большой приток студентов в два крупнейших ВУЗа региона и многие другие факторы не делают это поведение универсальным для всех адыгов. Но, тем не менее, оно имеет место и отвоевывает себе место под солнцем.

Подведем итог вышесказанному. Уважение старших у адыгов это целая система представлений и поведенческих норм. Зародившись на определенном уровне социальных и хозяйственных отношений, уважение старших выполняло роль хозяйственного регулятора, а также системы передачи знаний. Являясь изначально инструментом хозяйственной жизни, в последствии этот институт вышел за свои материальные рамки, превратившись в полноценного и тяжеловесного игрока в истории и социальных отношениях народа. Материальный базис (экономическая структура общества) адыгов, основанный на натуральном хозяйстве, начал стремительно меняться после вхождения в состав России. Отмена прежних сословных привилегий и резкое сокращение объемов пахотных и пашенных земель привели к ускоренному возникновению нуклеарных семей. Последовавшая за революцией 1917 года ломка «старых устоев» и создание новых экономических отношений, частью которого являлась коллективизация, окончательно уничтожила натуральные методы хозяйствования. Государственное регулирование, государственная монополия на землю и законодательные акты во многом уравняли положение членов семей. Постепенная урбанизация второй половины ХХ-го века и стремительный скачек 1990-ых годов, практически удвоившие число городских адыгов, напрямую сказались на институте уважения старших. Поставленные в новые условия «городского ритма» и наличия больших людских масс, уважение старших начало трансформироваться и стараться соответствовать новым жизненным реалиям. Произошедшие изменения в государственном устройстве и смена хозяйственных парадигм не поставили крест на институте уважения старших: уважение и почитание возраста остается весьма значимым ориентиром в жизни адыгов, который не утратил своей актуальности по сегодняшний день.

\section{Источники и материалы}

Бэлл 2007 - Бэлл Дж. Дневник пребывания в Черкесии в течение 1837-1839 годов. Нальчик: Издательский центр Эль-Фа, 2007. Т. 1. 327 с. 
Всероссийская 2002 - Всероссийская перепись населения 2002 года. Национальный состав. Доступ: http://www.perepis2002.ru/ct/html/TOM_04_01.htm (дата обращения 04.03.20).

Всероссийская 2010 - Всероссийская перепись населения 2010 года. Национальный состав и владение языками, гражданство. Доступ: https://www.gks.ru/free_doc/new_site/ perepis2010/croc/Documents/Vol4/pub-04-01.pdf (дата обращения 05.03.20).

Всесоюзная 1989 - Всесоюзная перепись населения 1989 года. Распределение городского и сельского населения областей и краев РСФСР по полу и национальности. Доступ: http:// www.demoscope.ru/weekly/ssp/rus_nac_89_gs.php?reg=3 (дата обращения 04.03.20).

Гвишиани 1989 - Гвишиани Д.М, Лапина Н.И. (под ред.). Краткий словарь по социологии. Москва: Политиздат, 1989. 479 с.

Гражданский 2001 - Гражданский кодекс РСФСР (утв. ВС РСФСР 11.06.1964) (ред. от 26.11.2001). Доступ: http://www.consultant.ru/document/cons_doc_LAW_1838/ (дата обращения: 19.05.20).

Губжоков 2018 - Губжоков М.Н. (сост.). Султан Хан-Гирей. Избранные труды и документы. Майкоп: ОАО Полиграф-Юг, 2018. 672 с.

Дубровин 1927 - Дубровин Н. Черкесы (Адыге). Краснодар: Издание общества изучения Адыгейской автономной области, 1927. 176 с.

Кон 1981 - Кон И.С. (под ред.). Словарь по этике. Москва: Политиздат, 1981. 430 с.

Леонтович 2010 - Леонтович Ф.И. Кавказ: Адаты горских народов. Нальчик: Издательство М. и В. Котляровых, 2010. 384 с.

Первушин 1970 - Первушин А.Г. (под ред.) Основы советского права: Учебник для с.-х. вузов. Москва: Юридическая литература, 1970. 566 с.

Хут 1989 - Хут Ш.Х. Несказочная проза адыгов. Майкоп: Адыгейское отделение Краснодарского книжного издательства, 1989. 333 с.

\section{Научная литература}

Бгажноков Б.Х. Основания гуманистической этнологии. Москва: Издательство РУДН, 2003. 272 с. Бгажноков Б.Х. Социальная организация семьи. Нальчик: Издательский отдел КБИГИ, 2010. $128 \mathrm{c}$.

Велеикая Н.Н. Языческая символика славянских архаических ритуалов. Москва: София, 2003. 237 c. https://www.litmir.me/br/?b=29186\&p=3 (дата обращения 03.03.20).

Гадагатль А.М. Героический эпос Нарты и его генезис. Краснодар: Краснодарское книжное издательство, 1967. 422 с.

Жумаганбетов Т.С. Власть Кагана в древнетюркской государственной организации // Вестник Челябинского государственного университета / отв. ред. А.Ю. Шатин. Вып. 27. 2008. Челябинск: Полиграфический участок издательского центра ЧелГУ, 2008. С. 14-19.

Заседателова Л.Б., Солдатова А.Е. Историко-этнографический очерк брачных и семейных традиций восточнославянского населения Северного Кавказа (XVII - нач. XX вв.) // Алгоритмы человечности. Опыт антропологического исследования / сост. и отв. ред. М.Н. Губогло. 2018 г. М.: Институт этнологии и антропологии РАН, 2018. С. 378-385.

Коджесау Э.Л. Патрономия у адыгов // Советская этнография / сост. Толстов С.П., отв. ред. О.А. Корбе Вып. 2. 1962. М.: Издательство академии наук СССР, 1962. С. 115-120.

Косвен М.О. Семейная община и патронимия. Москва: Издательство Академии наук СССР, 1963. $219 \mathrm{c}$.

Марзей А.С. Черкесское наездничество - «ЗекІуэ» (Из истории военного быта черкесов в XVIII - первой половине XIX в.). Нальчик: Издательский центр Эль-Фа, 2004. 302 с.

Меретуков М.А. Семья и брак у адыгских народов (XIX - 70-ые годы XX в.). Майкоп: Адыгейское отделение Краснодарского книжного издательства, 1987. 368 с.

Покровский М.Н. Русская история с древнейших времен. Москва: Государственное издательство, 1922. Т. 1.268 с. 
Сообиокова Н.И. Адыги-черкесы: люди, нравы, обычаи и традиции. Краснодар: Когорта, 2010. $352 \mathrm{c}$.

Цеева 3.А., Губжоков М.Н. История и культура адыгов: учебное пособие. Майкоп: Издательство АГУ, 2017. $228 \mathrm{c.}$

Шеуджен Э.А. (под ред.) Адыгея Историко-культурный очерк. Майкоп: Адыгейское отделение Краснодарского книжного издательства, 1989. 136 с.

Donezhuk, Murat Yu. *

\section{Respect for the elders among the Adygs: the emergence and transformation of the tradition}

DOI: $10.33876 / 2311-0546 / 2020-52-4 / 210-223$

The article discusses a set of norms and rules of behavior in relation to older people, which are deeply rooted in the Adyghe society. The aim of the study is to identify the motives for the emergence of this social institution and the reasons for its transformation, as well as to study the dynamics of the tradition from the beginning to the present day. Since the author sees the origins of the institution as determined not only by morality, but also by its close relationship with the economic foundations of society, the study aims to track the changes that have occurred in the material basis of the Adygs over the past 200 years and to estimate the influence of urbanization on the norms of manifestation of respectful attitude towards the elders. The author comes to the following conclusions: up to the second half of the 19th century, the Adygs relied mainly on diversified subsistence economy, which made families face the need to have many workers in the house. The prerequisites for the institution of respect for the elders formed in conditions of complex management and land law, which was completely in the hands of the eldest man in the family ("bolshak"). The involvement in the Russian economy that followed the end of the Caucasian War, and later the October Revolution, which changed the principles of land law, limited the power of the Adyghe "bolshak". The urbanization processes, in which the Adygs started to take part at the end of the 20th century, led to transformation of some of the traditional rules of external manifestations of respect for the elders.

Key words: Circassians, Adygs, respect for elders, habze

* Donezhuk, Murat Yu. - PhD-student, Institute of Ethnology and Anthropology RAS (Moscow, Russia).E-mail: donmur@iea.ras.ru

The research was supported by the Russian Foundation for Basic Research (RFFI, project No. 19-0900482 A)

\section{References}

Bgazhnokov, B.Kh. 2003. Osnovaniia gumanisticheskoi etnologii [The foundations of humanistic ethnology]. Moscow: RUDN Publishing House.

Bgazhnokov, B.Kh. 2010. Sotsial'naia organizatsiia sem'i [Social organization of the family]. Nalchik: Publishing Department of KBIGI.

Veletskaya, N. N. 2003. Iazycheskaia simvolika slavianskikh arkhaicheskikh ritualov [Pagan symbolism of the Slavic archaic rituals]. Moscow: Sofia. https://www.litmir.me/ $\mathrm{br} / \mathrm{b}=29186 \& \mathrm{p}=3$ (accessed 03.03.20).

Gadagatl, A.M. 1967. Geroicheskii epos Narty i ego genezis [Heroic epic of Nart and its genesis]. Krasnodar: Krasnodar Book Publishing House. 
Zhumaganbetov, T.S. 2008. Vlast' Kagana v drevnetiurkskoi gosudarstvennoi organizatsii [The power of Kagan in the ancient Turkic state organization]. Vestnik Cheliabinskogo gosudarstvennogo universiteta 27: 14-19.

Zatedatelova, L.B., Soldatova, A.E. 2018. Istoriko-etnograficheskii ocherk brachnykh i semeinykh traditsii vostochnoslavianskogo naseleniia Severnogo Kavkaza (XVII - nach. XX vv.) [Historical and ethnographic sketch of the marriage and family traditions of the East Slavic population of the North Caucasus (XVII - early XX centuries)]. In Algoritmy chelovechnosti. Opyt antropologicheskogo issledovaniia [Algorithms of humanity. Experience of anthropological research], edited by M.N. Guboglo, 378-385. Moscow: Institute of Ethnology and Anthropology, Russian Academy of Sciences.

Kojesau, E.L. 1962. Patronomiia u adygov [Patronomy of the Circassians]. Sovetskaia etnografiia 2: $115-120$.

Cosven, M.O. 1963. Semeinaia obshchina i patronimiia [Family community and patronymia]. Moscow: Publishing House of the Academy of Sciences of the USSR.

Marzey, A.S. 2004. Cherkesskoe naezdnichestvo - "ZekIue” (Iz istorii voennogo byta cherkesov v $X V I I I$ - per-voi polovine XIX $v$ [Circassian horseback riding - "ZekIue" (From the history of the military life of the Circassians in the XVIII - first half of the XIX century)]. Nalchik: El-Fa Publishing Center.

Meretukov, M.A. 1987. Sem 'ia i brak u adygskikh narodov (XIX-70-ye gody XX v.). [Family and marriage among Adyghe peoples (XIX - 70s of XX century)]. Maykop: Adyghe branch of the Krasnodar Book Publishing House.

Pokrovsky, M.N. 1922. Russkaia istoriia s drevneishikh vremen [Russian history since ancient times]. Moscow: State Publishing House.

Soobtsokova, N.I. 2010. Adygi-cherkesy: liudi, nravy, obychai i traditsii [Circassians of Adygea: people, customs, customs and traditions]. Krasnodar: Cohort.

Tseeva, Z.A.and M.N. Gubzhokov 2017. Istoriia i kul'tura adygov: uchebnoe posobie [The history and culture of the Circassians: a training manual]. Maykop: ASU Publishing House.

Sheujen, E.A. (Ed.) 1989. Adygeia Istoriko-kul'turnyi ocherk [Adygea Historical and Cultural Essay]. Maykop: Adyghe branch of the Krasnodar Book Publishing House. 


\title{
ФИЗИЧЕСКАЯ АНТРОПОЛОГИЯ
}

УДК 572

DOI: $10.33876 / 2311-0546 / 2020-52-4 / 224-231$

(С Е.В. Веселовская, О.М. Григорьева, И.Д. Бурцев

\author{
АНТРОПОЛОГИЧЕСКАЯ ХАРАКТЕРИСТИКА \\ ЭКСТРАОРДИНАРНОГО ЧЕРЕПА ИЗ С. ТХИНА (АБХАЗИЯ)*
}

\begin{abstract}
Настоящая работа посвящена изучению необычного черепа из раскопок кладбища у с. Тхина Очамчирского района, Абхазия. Череп с нижней челюстью, очень крупных размеров с ярко выраженным рельефом. Исследовали краниологические особенности черепа и черты внешнего облика индивида по выполненным на его основе графической и скульптурной реконструкциям. Принадлежность данного индивида к виду современного человека Hото sapiens не вызывает сомнений; возможно, присутствуют черты экваториального антропологического типа. Выраженное своеобразие, связанное с укрупнением общих размеров черепа и значительным развитием рельефа, может быть результатом гетерозиса при метисаџии далеко отстоящих антропологических типов, к которым принадлежали его родители.
\end{abstract}

Ключевые слова: антропологическая реконструкиия, внешний облик, череп из Абхазии, село Тхина

\section{Введение}

Раскопки проводились в 1971 и 1975 годах на кладбище с. Тхина Очамчирского района Абхазии под руководством И.Д. Бурцева, при участии Н.И. Бурчак-Абрамовича и Л.Т. Яблонского. Обнаруженный в результате раскопок 1974 года череп № 74 с нижней челюстью имеет очень хорошую сохранность. Данная находка сразу привлекла внимание своими очень крупными абсолютными размерами и сильно развитым рельефом. Поэтому, после изучения стандартных краниологических измерений, было решено провести целый ряд дополнительных антропологических исследований. А именно, нас заинтересовало, насколько обнаруженные очень большие размеры мозгового чере-

Веселовская Елизавета Валентиновна - д.и.н., главный научный сотрудник Центра физической антропологии, Институт этнологии и антропологии РАН (Москва, Ленинский пр. 32-а) Эл. почта: veselovskaya.e.v.@yandex.ru

Григорьева Ольга Михайловна - к.б.н., старший научный сотрудник Центра физической антропологии, Институт этнологии и антропологии РАН (Москва, Ленинский пр. 32-а) Эл. почта: labrecon@yandex.ru

Бурцев Игорь Дмитриевич - к.и.н., журналист, работал в Институте Востоковедения РАН (Москва, ул. Рождественская,12/1). Эл. Почта: inhomin@yandex.ru

* Исследование выполнено в рамках темы НИР «Эволюционный континуум рода Ното». Подтема «Антропология древних и современных популяций» 
па соответствуют его внутреннему содержанию, т.е. необходимо было измерить объем мозговой капсулы. Также важно было узнать внешний облик данного индивидуума для установления его принадлежности к тому или иному антропологическому типу, что и было сделано путем выполнения графической и скульптурной реконструкций. Использование разработанной в Лаборатории специальной программы «Алгоритм внешности» позволило выявить также некоторые индивидуальные особенности данной находки.

\section{Методы исследования}

Череп № 74 был измерен по классической антропометрической программе (Алексеев, Дебеи 1961) и по специальной программе для антропологической реконструкции (Веселовская 2018: 38-54). Объем мозговой коробки измеряли прямым заполнением ее сыпучим материалом.

Определение возраста проводилось по зарастанию черепных швов и степени стертости жевательной поверхности зубов. Швы мозгового отдела венечный и стреловидный заросли в значительной степени. Швы лицевой части черепа в основном заращены. Зубы стерты значительно. По совокупности признаков возраст оценивается в 60-65 лет.

Было проведено восстановление прижизненного облика. Для этого использовали программу «Алгоритм внешности». Этот разработанный недавно методический подход служит комплексным руководством для перехода от размеров и описательных признаков черепа к соответствующим размерам и признакам головы. Он предлагает на базе последовательной детальной фиксации размеров и описательных характеристик черепа переходить к размерам головы в целом и отдельных ее элементов, а также давать антропологическую характеристику качественным признакам внешности. Применение метода «Алгоритма внешности» способствует более точному воспроизведению по черепу индивидуальных черт внешнего облика (благодаря широкому применению регрессионного анализа многие размеры головы рассчитывают на основе черепных), а также дополняет графический или скульптурный портрет антропологической характеристикой лица в терминах «словесного портрета». Описание внешности строится на системе индексов, которые характеризуют относительные пропорции. Использование этой программы позволяет восстанавливать внешний облик ряда представителей конкретных популяций и не обязательно в виде портретов. Возможно получение бланков прижизненных размеров и описательных признаков. Сопоставление результатов такой реконструкции с современным населением соответствующих территорий вооружает антропологов новыми инструментами для решения вопросов этногенеза, адаптации популяций, эпохальной изменчивости.

\section{Описание черепа}

Обнаруженный в результате раскопок 1974 года у с. Тхина череп № 74 обладает хорошей сохранностью, имеется нижняя челюсть (Рис. 1). Несколько поврежден участок альвеолярного отростка верхней челюсти. Череп очень крупных размеров с ярко выраженным рельефом в области глабеллы, надбровных дуг, затылка. Отличительной особенностью является гиперразвитие сосцевидных отростков височных костей. Имеется кость инков в области ламбдовидного шва также очень крупная. В месте 


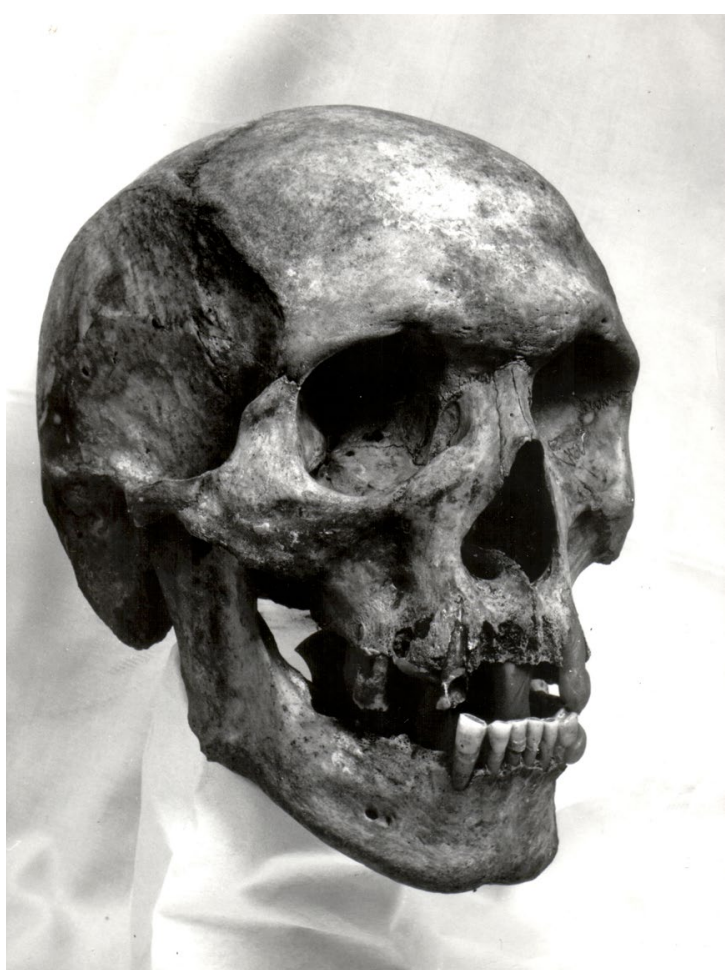

Рис. 1. Череп № 74 из раскопок кладбищуа у c. Тхина, Очамчирский район, Абхазия.

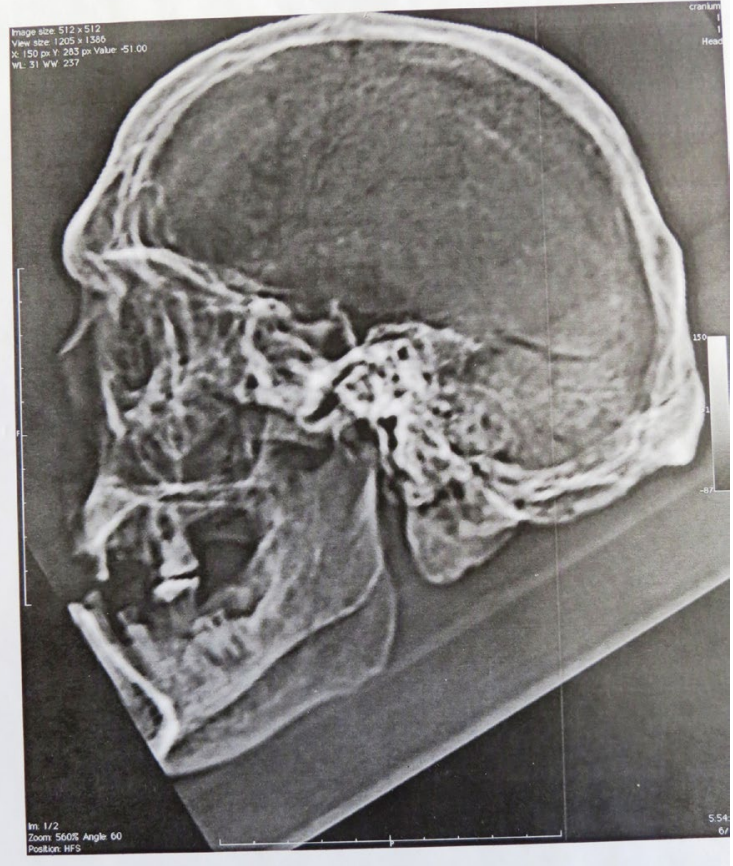

Рис. 2. Компьютерная томограмма черепа № 74. Хорошо виден рельеф в области глабелль и затылка. перегиба затылочной кости имеется дополнительный шов (Рис. 2).

Череп № 74 демонстрирует очень крупные размеры, большинство их попадает в категории больших и очень больших (Алексеев, Дебеи 1961). Мозговой отдел головы велик. Вместимость мозговой капсулы, измеренная путем заполнения сыпучим материалом, составила 1440 куб. см., что вполне соответствует среднему показателю объема мозга для современных мужчин. Лицо также очень крупное. Однако по относительным пропорциям данный индивид вписывается в размах вариаций для человека современного вида.

Череп ранее был измерен М.А. Колодиевой и сопоставлен с серией современных абхазов; М.М. Герасимовой было осуществлено дополнительное антропометрическое и антропоскопическое изучение (Буриев, Колодиева 1987: 21-23). Ниже мы приводим характеристику черепа № 74 с учетом вышеназванных исследований.

К особенностям данного черепа в первую очередь следует отнести значительное развитие рельефа, как в области глабеллы и надбровья, так и в затылочной и височной областях. Этот факт, а также необычайно крупные сосцевидные отростки височной кости свидетельствуют о чрезвычайном развитии мускулатуры. Особого описания заслуживает затылочная кость. Перегиб затылка от тела кости к ее чешуе представляет собой острый угол, в месте перегиба видны следы дополнительного шва. Выйные линии в виде гребней выражены чрезвычайно, что находит аналогии в краниосериях населения верхнего палеолита. Чешуя затылочной кости очень большой величины.

Череп отличает резкая горизонтальная профилировка подносовой 
области, значительная выраженность клыковых ямок. Для находки из с. Тхины характерны брахикрания, гипсикрания, малая высота изгиба лба, большая длина лицевого отдела, резкая горизонтальная профилировка (по сравнению с массивными черепами абхазской серии). Значительно увеличены продольный диаметр черепа, скуловой диаметр, ширина орбит, выступание глабеллы и надбровных дуг.

Очень хорошо развиты височные линии, расстояние между верхними - 112 мм. Вообще череп отличается сильным развитием рельефа: шероховатости в местах прикрепления мышц имеют форму гребней, на скуло-челюстном шве и даже на скуловом отростке височной кости.

Нижняя челюсть характеризуется огромной величиной мышелковой ширины. Ветвь нижней челюсти очень высокая, относительно узкая. Высота тела и толщина тела нижней челюсти не выходят за пределы вариаций у современного человека. В отличие от большинства черепов, на нижней челюсти в области подбородка имеется по два питательных отверстия с каждой стороны. Ниже приведена таблица с указаниями основных размеров, взятых на исследуемом черепе, и рассчитанные по ним прижизненные размеры лица и мозгового черепа, вычисленные с использованием программы «Алгоритм внешности». (Табл. 1). Для этого сначала рассчитали прижизненные признаки головы на основе размеров черепа. Размеры живого лица и черепа получили путем прибавления толщины мягких тканей в соответствующих точках.

Таблица 1

Расчет прижизненных размеров головы за счет прибавления толщины мягких тканей в соответствующих точках

\begin{tabular}{|c|c|c|c|c|}
\hline Размер на черепе & мм & Размер на живом лице & мм & $*$ \\
\hline Продольный диаметр gl-op & 196 & Продольный диаметр gl-op & 212 & ОБ \\
\hline Поперечный диаметр еu-eu & 156 & Поперечный диаметр eu-eu & 170 & Б \\
\hline Ширина лба со-со & 138 & Ширина лба со-со & 150 & \\
\hline Наименьшая ширина лба ft-ft & 117 & Наименьшая ширина лба ft-ft & 129 & ОБ \\
\hline Верхняя ширина лица fmt-fmt & 117 & Ширина лица на уровне глаз & 129 & \\
\hline Ширина орбиты en (cr) - ek (cr) & 48 & Длина глазной щели & 36 & \\
\hline Скуловой диаметр zy-zy & 157 & Скуловой диаметр zy-zy & 169 & ОБ \\
\hline Симотическая ширина & 11 & Ширина переносья & 17 & \\
\hline Ширина спинки носа nm-nm & 15 & Ширина спинки носа & 21 & \\
\hline $\begin{array}{l}\text { Ширина между альвеолярными } \\
\text { возвышениями клыков с1-с1 }\end{array}$ & 42 & Ширина носа & 42 & Б \\
\hline $\begin{array}{l}\text { Ширина между альвеолярными } \\
\text { возвышениями клыков с1-с1 }\end{array}$ & 42 & $\begin{array}{l}\text { Расстояние между } \\
\text { носогубными складками }\end{array}$ & 57 & $\mathrm{C}$ \\
\hline $\begin{array}{l}\text { Расстояние между 5-ми зубами } \\
\text { верхней челюсти }\end{array}$ & 60 & Ширина рта che-che & 64 & $\mathrm{C}$ \\
\hline
\end{tabular}


Таблица 1 (продолжение)

\begin{tabular}{|c|c|c|c|c|}
\hline Размер на черепе & мм & Размер на живом лице & мм & \\
\hline $\begin{array}{l}\text { Ширина между подбородочными } \\
\text { отверстиями me-me }\end{array}$ & 55 & Ширина подбородка & 70 & ОБ \\
\hline $\begin{array}{l}\text { Угловая ширина } \\
\text { нижней челюсти go-go }\end{array}$ & 107 & $\begin{array}{l}\text { Угловая ширина нижней } \\
\text { челюсти go-go }\end{array}$ & 119 & M \\
\hline $\begin{array}{l}\text { Физиономическая высота лица } \\
\text { tr- (cr)-gn }\end{array}$ & 203 & $\begin{array}{l}\text { Физиономическая } \\
\text { высота лица tr -gn }\end{array}$ & 212 & ОБ \\
\hline $\begin{array}{l}\text { Морфологическая высота лица } \\
\text { so-gn }\end{array}$ & 149 & $\begin{array}{l}\text { Морфологическая высота } \\
\text { лица от нижнего края бровей }\end{array}$ & 157 & $\mathrm{O}$ \\
\hline Высота лба tr (cr)-so & 55 & $\begin{array}{l}\text { Высота лба tr - нижний } \\
\text { край бровей }\end{array}$ & 55 & $\mathrm{C}$ \\
\hline Высота орбиты & 39 & Высота глазной щели & 16,5 & Б \\
\hline Скулочелюстная высота zy-go & 70 & Скулочелюстная высота zy-go & 77 & \\
\hline Высота носа so-ss & 69 & $\begin{array}{l}\text { Высота носа от нижнего } \\
\text { края бровей }\end{array}$ & 69 & Б \\
\hline $\begin{array}{l}\text { Высота положения } \\
\text { раковинного гребня con-ss }\end{array}$ & 18 & Высота крыла носа & 18 & Б \\
\hline Высота верхней челюсти ss-sd & 18 & Высота верхней губы & 18 & $\mathrm{C}$ \\
\hline Высота нижней челюсти & 53 & Высота нижней челюсти & 62 & ОБ \\
\hline Высота подбородка sm-gn & 25 & Высота подбородка sm-gn & 33 & $\mathrm{C}$ \\
\hline
\end{tabular}

* Примечание. В правой колонке таблицы представлены категории, в которые попадает каждый признак. ОБ - очень большой; Б - большой; С - средний.

\section{Восстановление внешнего облика по черепу № 74}

С использованием программы «Алгоритм внешности» была проведена реконструкция внешнего облика по данному черепу, и выполнены контурная (Рис. 3a), графическая (Рис. 3б) и скульптурная (Рис. 4) реконструкции. В таблице 2 представлены прижизненные размеры лица, полученные с использованием уравнений регрессии (Табл. 2). 
Таблица 2

Уравнения регрессии, использованные для расчета прижизненных размеров

\begin{tabular}{|c|c|c|}
\hline $\begin{array}{l}\text { Прогнозируемый признак } \\
\text { на лице }\end{array}$ & Признак на черепе & Уравнение регрессии \\
\hline $\begin{array}{l}\text { Физиономическая } \\
\text { высота лица (ФВЛ) }\end{array}$ & $\begin{array}{l}\text { Морфологическая } \\
\text { высота лица (МВЛ) - } 149\end{array}$ & $\begin{array}{l}\text { ФВЛ=95,515+0,748x (МВЛ+7мм* }) \\
212\end{array}$ \\
\hline Высота уха (ВУ) & $\begin{array}{l}\text { Морфологическая } \\
\text { высота лица }(\text { МВЛ })-149\end{array}$ & $\begin{array}{l}\mathrm{BY}=55,488+0,073 \times\left(\text { МВЛ+7 } \mathrm{MM}^{*}\right) \\
67\end{array}$ \\
\hline Ширина носа (ШН) & $\begin{array}{l}\text { Ширина между клыковы- } \\
\text { ми точками (ШМК) - } 42\end{array}$ & $\begin{array}{l}\text { ШН=23,035+0,444xШМК } \\
42\end{array}$ \\
\hline $\begin{array}{l}\text { Ширина между носогубны- } \\
\text { ми складками (ШМН-ГС) }\end{array}$ & $\begin{array}{l}\text { Ширина между клыковы- } \\
\text { ми точками (ШМК) - } 42\end{array}$ & $\begin{array}{l}\text { ШМН-ГС }=21,744+0,843 x Ш М К \\
57\end{array}$ \\
\hline Ширина фильтра (ШФ) & $\begin{array}{l}\text { Ширина между клыковы- } \\
\text { ми точками (ШМК) - } 42\end{array}$ & $\begin{array}{l}\text { Ш=7,295+0,118xШМК } \\
12\end{array}$ \\
\hline Ширина рта (ШР) & $\begin{array}{l}\text { Ширина зубной дуги } \\
\text { (Pm2- Pm2)-60 }\end{array}$ & $\begin{array}{l}Ш \mathrm{~W}=21,817+0,700^{\prime}(\mathrm{Pm} 2-\mathrm{Pm} 2) \\
64\end{array}$ \\
\hline
\end{tabular}

* - толщина мягких тканей в точке гнатион.

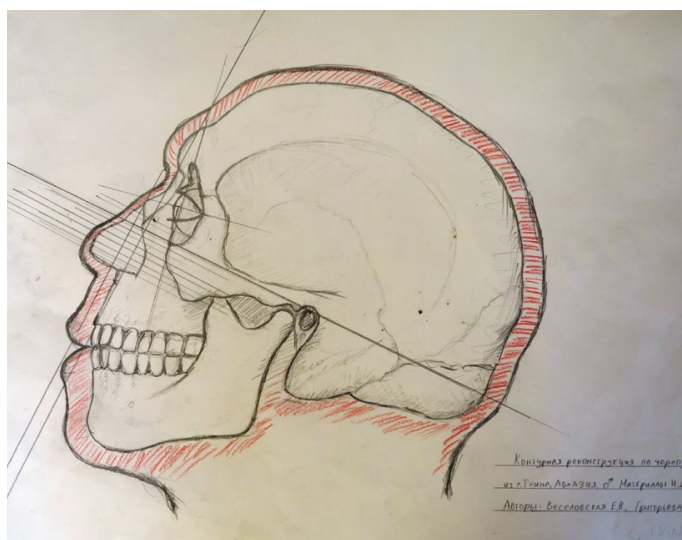

Рис. 3а. Контурная реконструкиия по черепу № 74. Авторы: Веселовская Е.В., Григорьева О.М.

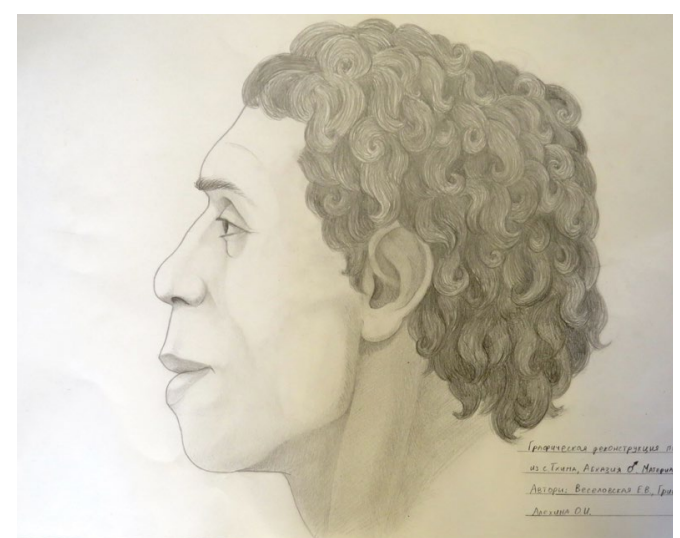

Рис. 3б. Графическая реконструкция по черепу № 74. Авторы: Веселовская Е.В., Григорьева О.М., Алехина О.В.

\section{Словесный потрет - описание прижизненного облика}

Согласно программе описания словесного портрета, у исследованного индивида обнаруживаются следующие характеристики его внешности.

Отмечается мезокефалия на границе с брахикефалией. Головной указатель равен 80, следовательно, голова в лобно-затылочном направлении средней длины.

\section{Форма головы в профиль округлая}

Лицо высокое и широкое, очень крупных размеров. Скуловой диаметр достигает огромной величины - 169 мм 


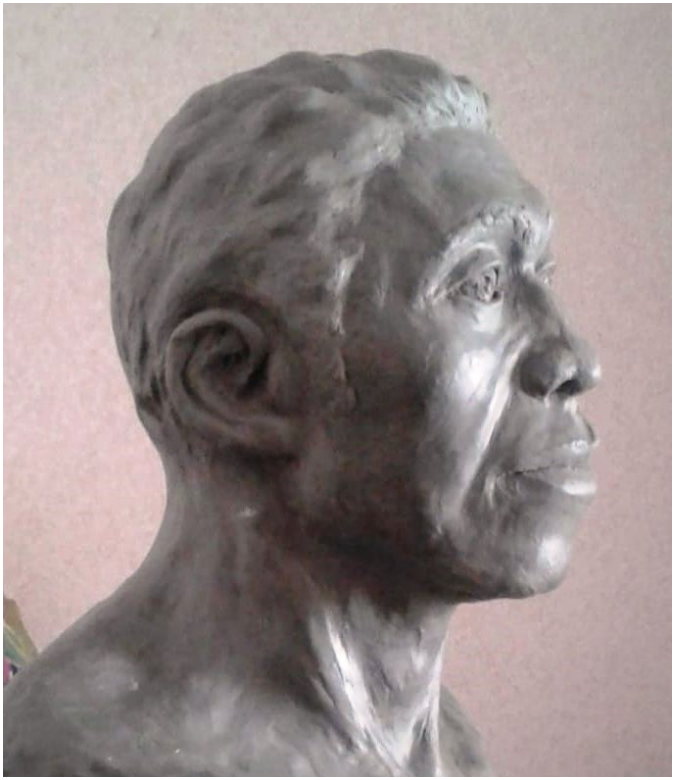

Вертикальная профилировка челюстная, фиксируется лицевой прогнатизм. Клыковые ямки на черепе очень глубокие, что усугубляет визуальное впечатление выступания вперед челюстного отдела.

Горизонтальная профилировка значительная.

Направление лба наклонное, линия лба прямая. Лоб по высоте средний. Надбровный рельеф очень мощный. Надбровные дуги заходят за середину надглазничного края орбиты.

Контур бровей прямой. Положение разреза глаз горизонтальное.

Глазные яблоки выпуклые. Глаза крупные. Складка верхнего века выражена слабо. Скулы не выступающие.

Переносье глубокое и узкое. Нос в

Рис. 4. Скульптурная реконструкция по черепу крыльях широкий, по высоте короткий, № 74. Авторы: Веселовская E.В., Григорьева выступает вперед незначительно. В проO.M. филь спинка носа с легкой горбинкой.

Верхняя губа относительно невысокая. Ширина ротовой щели большая.

Нижняя челюсть в углах узкая. Подбородок по высоте и ширине средний, подбородочный выступ не выражен.

\section{Заключение}

Облик, представленный на реконструированном портрете, не вызывает сомнений в принадлежности данного индивида к современному виду человека Homo sapiens, хотя и обладает рядом особенностей. Это, в первую очередь крупные размеры головы, с сильно развитыми мышцами, жевательными и шейными. При этом, собственно объем мозга вполне укладывается в пределы показателей, характерных для мужских популяций современного человека. В целом исследуемый индивид относится к европеоидному антропологическому типу, но также выделяются некоторые признаки, характерные для экваториальной расы. А именно: широкий в крыльях, мало выступающий довольно короткий нос, лицевой прогнатизм, значительное развитие челюстного отдела, крупные размеры рта.

По преданиям местных жителей известно, что отцом Хвита, так звали исследуемого нами индивидуума, являлся абхаз, который взял себе в жены необычную женщину. В 1975 г. при раскопках на сельском кладбище с. Тхина были изъяты останки женщины, предположительно матери Хвита, череп которой отличался большой длиной и прогнатностью (Буриеев, Колодиева 1987). В дальнейшем, образец тканей ее останков был передан в Университет Копенгагена. Результаты генетического анализа пока еще не опубликованы, но по устному сообщению датских генетиков, у этой женщины была типирована гаплогруппа, распространенная в Африке, южнее Сахары, а также на генетическом уровне установлено родство этой женщины и изученного нами индивидуума.

Исходя из этого, можно предположить, что крупные размеры исследованного че- 
репа объясняются гетерозисными явлениями в результате возможной принадлежности родителей к далеко отстоящим антропологическим типам (европеоидный и экваториальный).

\section{Научная литература}

Алексеев В.П., Дебеи Г.Ф. Краниометрия. Методика антропологических исследований. М.: Наука, 1964.

Буриев И.Д., Колодиева М.А. Результаты предварительного исследования черепа из с. Тхина,

Абхазской АССР. Доклады МОИП, 1985. Общая биология. М.: Наука, 1987. С. 21-23.

Веселовская E.B. «Алгоритм внешности» - комплексная программа антропологической реконструкции // Вестник Московского университета. Серия XXIII. Антропология. М.: Издательский Дом МГУ. 2018. № 2. С. 38-54.

\section{References}

Alekseev V.P., and G.F Debets. 1964. Kraniometriia. Metodika antropologicheskikh issledovanii. [Craniometry. Methods of anthropological research]. Moscow: Nauka.

Burtsev I.D., and M.A. Kolodieva. 1987. Rezul'taty predvaritel'nogo issledovaniia cherepa iz s. Tkhina, Abkhazskoi ASSR. [Results of a preliminary study of a skull from the village of Thin, Abkhazian ASSR]. Doklady MOIP, 1985. Obshchaia biologiia [Reports of MOIP, 1985. General biology], 21-23. Moscow: Nauka.

Veselovskaia E.V. 2018. “Algoritm vneshnosti’ - kompleksnaia programma antropologicheskoi rekonstruktsii ["Algorithm of appearance" - a comprehensive program of anthropological reconstruction]. Vestnik Moskovskogo universiteta. XXIII. Antropologiia 2: 38-54.

Veselovskaya, Elizaveta V., Grigorieva, Olga M., and Burtsev, Igor D.*

\section{Anthropological description of an extraordinary skull from the village of Thin (Abkhazia)}

DOI: $10.33876 / 2311-0546 / 2020-52-4 / 224-231$

This work is devoted to the study of a very unusual skull from the village of Thina, Abkhazia. The skull has the lower jaw, is very large and rather robust with pronounced relief. The metric traits of this skull and its external appearance were studied based on graphic and sculptural reconstructions made from it. It is concluded that this individual belongs to the modern human species Homo sapiens, one of its Equatorial variants. The unusual appearance of the skull might be explained by heterosis caused by possible miscegenation in this individual's ancestors.

Key words: anthropological reconstruction, appearance, skull from the village of Thina, Abkhazia

* Veselovskaya, Elizaveta V. - Dr. of Hist., Institute of Ethnology and Anthropology RAS (Moscow, Leninsky Pr. 32-a). E-mail: veselovskaya.e.v.@yandex.ru

Grigorieva, Olga M. - PhD in biol., Institute of Ethnology and Anthropology RAS (Moscow, Leninsky Pr. 32-a). E-mail:labrecon@yandex.ru

Burtsev, Igor D. - PhD in Hist., Institute of Oriental Studies of the RAS (12/1 Rozhdestvenka str., Moscow). E-mail: inhomin@yandex.ru

The research is published as part of the Research Plan of the Institute of Ethnology and Anthropology (Russian Academy of Sciences, Moscow), "The evolutionary continuum of the genus Homo", Subtopic "Anthropology of Ancient and Modern Populations" 


\title{
ПОЛИМОРФИЗМ ГЕНОВ ДОФАМИНОВОГО ТРАНСПОРТЕРА И ДОФАМИНОВОГО РЕЦЕПТОРА D2 АССОЦИИРОВАН С ОСОБЕННОСТЯМИ ТЕЛОСЛОЖЕНИЯ*
}

\begin{abstract}
Одним из актуальных междисииплинарных направлений научных исследований является изучение механизмов, лежащих в основе формирования конституции человека. Полиморфизм генов нейромедиаторных систем довольно часто рассматривается в связи с различными аспектами состояния психики человека и особенностями телосложения. Цель исследования - поиск ассоцииций полиморфизма генов дофаминового транспортёра и дофаминового рецептора D2 с особенностями телосложения и функииональными характеристиками сердечно-сосудистой системы. Использованы материаль комплексного антропогенетического обследования 216 юношей и девушек в возрасте 16-23 лет, проведенного в республике Мордовии. Соматометрическая программа включала измерение длины и массы тела, обхватов талии и бёдер, толщины жировых складок на туловище и конечностях (под лопаткой, на плече, предплечье, животе, бедре и голени). Из функииональных показателей сердечно-сосудистой системь измерены систолическое и диастолическое артериальное давление, частота пульса. У всех респондентов собраны образиь буккального эпителия для генотипирования по локусу 3'- UTR VNTR DAT1 дофаминового переносчика и по локусу DRD2/ANKK1 Taq1A (rs1800497) дофаминового рецептора второго типа. С помощью U-критерия Манна-Уитни проведен сравнительный анализ средних значений морфофункциональных показателей в группах носителей различных генотипов исследуемых генов, по результатам которого выявлены достоверно значимые $(p<0,05)$ ассоциачии: у девушек, обладающих хотя бы одним аллелем 9 по локусу DAT1 выше значения массы тела и обхвата бедер; у девушек - носителей генотипа $C / C$ по локусу DRD2/ANKK1 Taq1A больше показатели массы тела, индекса массы тела, обхвата талии, жировых складок на животе, плече и бедре, а также
\end{abstract}

Васильева Александра Александровна - магистр (биология, антропология), аспирант кафедры антропологии биологического факультета, МГУ им. М.В. Ломоносова (Москва, Ленинские горы, д. 1, стр. 12). Эл. почта: vasileva@mail.bio.msu.ru.

Василий Александрович Васильев - к.б.н., старший научный сотрудник лаборатории организации генома, Институт биологии гена РАН (Москва, улица Вавилова, д. 34/5). Эл. почта: shunka@mail.ru

Негашева Марина Анатольевна - д.б.н., профессор кафедры антропологии биологического факультета, МГУ им. М.В. Ломоносова (Москва, Ленинские горы, д. 1, стр. 12). Эл. почта: negasheva@mail.ru

* Работа выполнена при финансовой поддержке гранта Российского фонда фундаментальных исследований № 18-09-00290 «Биологические и социальные факторы микроэволюционных изменений морфофункционального статуса и уровня полового диморфизма в популяциях современного населения» и программы «Постгеномные технологии и перспективные решения в биомедицине» 
выле частота пульса по сравнению с обладательницами других генотипов. Для юношей достоверных различий морфофункциональных признаков у носителей разных генотипов обнаружено не было. Выявленные ассоциации полиморфизма генов DAT1 и DRD2 с морфофункииональными характеристиками, возможно, обусловлены комплексным влиянием генетических факторов на формирование особенностей телосложения в прочессе онтогенеза человека. Полученные результаты могут представлять интерес для исследователей, занимаюшихся изучением генетических основ морфологической конституции, а также могут быть использованы в персонализированной медицине.

Ключевые слова: антропометрия; индекс массы тела; жироотложение; молодёжь Мордовии; генетика человека; DAT1; DRD2/ANKK1 Taq1A

\section{Введение}

Ген дофаминового транспортёра $D A T 1$ и ген дофаминового рецептора второго типа $D R D 2$ - одни из наиболее популярных у исследователей генов дофаминовой системы, которые часто рассматривают в связи с различными аспектами состояния психики человека. В последнее время полиморфизм этих генов также изучается в ассоциации с телосложением.

Переносчик дофамина ( $S L C 6 A 3$, или $D A T 1)$ играет важную роль в дофаминергической нейротрансмиссии, ограничивая активность дофаминергической системы в синапсах путем обратного захвата нейромедиатора в пресинаптический терминал. Ген человеческого транспортера дофамина (DAT1/SLC6A3) локализован на хромосоме 5p15.3. В данном гене обнаружен VNTR-полиморфизм (варьирующее число тандемных повторов) в 3'-некодирующей области (3'UTR) с числом повторов от 3 до 11. Длина одного повтора 40 пар оснований (п.н.). Два наиболее часто встречающихся в популяциях аллеля состоят из 9 и 10 повторов (Vandenbergh et al. 1992). Повышенный уровень экспрессии DAT1 чаще связывают с аллелем 10, чем с аллелем 9 (VanNess et al. 2005), хотя некоторые исследователи сообщали об обратном (Van Dyck et al. 2005) или об отсутствии ассоциаций между генотипами и показателями экспрессии DAT1 (Krause et al. 2006, Costa et al. 2011). Функциональный полиморфизм DAT1 VNTR напрямую изменяет плотность и активность дофаминового транспортёра в мозге, в основном, в полосатом теле. У лиц, имеющих две копии аллеля 10, концентрация переносчика выше и, значит, меньше дофамина в синаптической щели, чем у носителей аллеля 9 (Heinz et al. 2000). Следовательно, пресинаптический нейрональный мембранный белок DAT1 играет ключевую роль в прекращении нейротрансмиссии дофамина благодаря активному обратному захвату дофамина в пресинаптический терминал (Giros, Caron 1993). Ген DATl (SLC6A3) участвует в эмоциональной обработке данных и связанных с нарушением регуляции передачи дофамина патологиях, например, в развитии депрессивного расстройства. И депрессия, и ожирение ассоциированы с генотипом 9/9 рассматриваемого гена (Bieliński et al. 2017). На примере группы из 506 женщин была показана связь гомозиготности по аллелю с девятью повторами и более высоких значений индекса массы тела (ИМТ) (Sikora et al. 2013). Другие исследователи не выявили связи гена DAT1 с ИМТ и ожирением (Uzun et al. 2015).

Ген $D R D 2$, кодирующий дофаминовый рецептор $\mathrm{D} 2$, расположен на длинном плече хромосомы 11 (11q22.3-11q23.1) (Eubanks et al. 1992). Первоначально считалось, 